\title{
SISTEMATIZAÇÃO DE PRECEDENTES E ORDENAMENTO JURÍDICO: PROPOSTA DE UM PARADIGMA TEÓRICO
}

\author{
SYSTEMATIZATION OF PRECEDENTS AND LEGAL SYSTEM: PROPOSAL OF A \\ THEORETICAL PARADIGM
}

\begin{abstract}
Doutor (UNIFOR) e Mestre (UFC) em Direito Constitucional. Pós-Graduado Lato Sensu em Direito Processual Civil (UFC). Professor da UNICHRISTUS (graduação e pósgraduação). Procurador do Município de Fortaleza. Advogado.

E-mail: juracimourao@gmail.com
\end{abstract}

Recebido em: 29/11/2016

Aprovado em: 13/06/2017

Doi: $10.5585 /$ rdb.v18i7.547

RESUMO: Não existe ainda uma específica teoria sobre a sistematização dos precedentes, sendo utilizado irrefletidamente o modelo de sistema normativo clássico concebido pelo positivismo para explicar o ordenamento jurídico, segundo uma lógica formal que resulta em estrutura piramidal e hierarquizada de relações unidirecionais. Tem-se um padrão fundacionalista. Assim, os precedentes são reduzidos a normas e escalonados pelo grau da corte emissora, presumindo-se que possuem vigência, promulgação e revogação, sendo suas incompatibilidades tratadas como antinomias normativas. Contudo, tal modelo não se ajusta aos precedentes, que não podem ser reduzidos a normas, pois são um ganho hermenêutica que possui força vinculante variável. Consequentemente, as incoerências não são antinomias, não podendo ser solucionadas como tais. Exige-se, então, um modelo coerentista de sistema pautado em relações substanciais de lógica dialética, que estruturam o conjunto em uma rede de mútuas relações multidirecionais, sendo eventuais incoerências solucionadas por mensuração da força hermenêutica de cada julgado. Esse modelo evidencia que sistema jurídico é um sistema complexo, formado por dois subsistemas: um normativo - formado por normas constitucionais, legais e regulamentares, cuja estruturação tenta ser piramidal -, e outro de precedentes - estruturado em rede, e formado pelos julgados das várias cortes que tenha gerado um ganho hermenêutico para o sistema jurídico como um todo. $\mathrm{O}$ presente artigo pretende, mediante revisão bibliográfica e análise jurisprudencial, demonstrar um novo modelo de ordenamento jurídico , que possui uma nova lógica e um novo referencial teórico, se considerados os modelos mais conhecidos e utilizados.

Palavras-chave: Precedentes. Sistema. Ordenamento jurídico. Integridade.

ABSTRACT: There is not yet a theory about the systematization of precedents, and the normative system model conceived by positivism for the legal order is used in an unthinking way, which results in the pyramidal and hierarchical structure of unidirectional relations. It is a foundationalist model. Thus, precedents are reduced to norms and staggered according to the degree of the enacting court, and their incompatibilities are treated as antinomies. Notwithstanding, such a model does not fit the precedents, which cannot be reduced to norms, since they are a hermeneutical gain, having variable binding force. Consequently, inconsistencies are not antinomies. It requires a coherentist system model based on substantial relations of dialectical logic, which structure the whole in a network of mutual multidirectional interactions, 
and its eventual inconsistencies are solved by measuring the hermeneutic force. This paper intends to demonstrate the inadequacy of the foundationalist model by proposing a complex legal system formed by two subsystems: a normative - composed by constitutional, legal and regulatory norms, whose structure tries to be pyramidal - , and another one of precedents structured in a network, and formed by the decisions of the multiple courts that has generated a hermeneutical gain for the legal system as a whole.

Keywords: Systematization of precedents. Legal system. Integrity.

SUMÁRIO. Introdução. 1. Positivismo, formalismo e fundacionalismo nas concepções de ordenamento jurídico enquanto sistema piramidal e hierarquizado. 2. Os precedentes judiciais na pirâmide axiomática fechada: registro de uma incompatibilidade. 3. Um novo começo: direito como integridade e o sistema coerêncista de precedentes. Conclusão. Referências Bibliográficas.

\section{INTRODUÇÃO}

A tradicional concepção de sistema jurídico, como um ordenamento normativo hierarquizado e piramidal, pautado por relações eminentemente formais, não se ajusta aos precedentes judiciais. Não é possível disciplinar as interações entre os vários julgados pelos padrões sistêmicos erigidos para as normas jurídicas em geral, dada sua base positivista e formalista, calcada em relações assimétricas (também chamadas de abertas) regidas por relações de lógica formal e vinculação fixa. Esse modelo não serve, assim, de maneira apropriada para explicar a estruturação do subsistema que os precedentes formam.

A despeito dessa incompatibilidade e a necessidade de buscar um novo referencial, há uma inércia teórica na doutrina brasileira, que enxerga a ascensão dos precedentes judiciais desde uma teoria que não foi concebida para eles, importando uma acrítica aplicação da teoria do ordenamento nos moldes pensados por Kelsen e Bobbio. Chega-se ao ponto de forçosamente atribuir noções e qualidades aos precedentes judiciais para que eles possam se (mal) adequar às concepções próprias das normas legislativas, gerando contradição entre as razões e as finalidades que fazem os inúmeros julgados fruírem atualmente de grande importância na teoria e na prática do Direito.

Esse é o problema para o qual se busca apontar solução neste trabalho.

Os precedentes judiciais exercem função hermenêutica bastante específica no ordenamento jurídico, a qual demanda relações simétricas (também denominadas de circulares) determinadas por uma lógica dialética com vinculação variável por critérios de justificação, coerência e integridade. Tem-se, assim, relações de reforços e desafios, sem os rigorosos critérios binários formais de compatível/incompatível ou vigente/revogado. Isso impede a distribuição de precedentes em níveis hierárquicos fixos, impondo a substituição da figura piramidal e hierarquizada de partes fixas e pré-determinadas por uma forma em rede, cujas partes interagem de maneira variável segundo as circunstâncias hermenêuticas de formação e aplicação dos vários precedentes, e o contexto geral em que inseridos. Essa é a hipótese que se apresenta e se defende no presente trabalho para solução do problema da inadequação do modelo geral de sistema jurídico.

Como resultado, tem-se um sistema jurídico complexo, formado por dois subsistemas: o subsistema normativo - composto por normas constitucionais, legais e regulamentares, cuja a estrutura busca ser piramidal -, e o sistema de precedentes - integrado pelos julgados dos vários tribunais estruturados em rede. Normas como a do novo Código de Processo Civil a respeito de precedentes disciplinam a relação entre esses dois subsistemas e entre os vários elementos integrantes do subsistema de precedentes. 
O presente texto busca expor, portanto, as razões fundamentais da incompatibilidade entre a conhecida teoria do ordenamento jurídico e a sistematização de precedentes e demonstrar que o modelo proposto apresenta soluções a questões em que aquela falha. Para tanto, far-se-á a exposição de três modelos de ordenamento jurídico conhecidos (o modelo de Kelsen/Bobbio, de Hart/Raz, e de Alf Ross, com seu modelo de árvore invertida) para, em seguida, mostrar suas insuficiências para estruturação do subsistema de precedentes. Em seguida, serão expostos os cincos pontos próprios de uma teoria geral dos sistemas, e como cada um deles deve ser explicado pela proposta aqui apresentada, construída segundo o referencial teórico já indicado.

Ao final, espera-se concluir com indicações dos pontos fundamentais da hipótese apresentada de modo a orientar futuros estudos e aplicações.

\section{POSITIVISMO, FORMALISMO E FUNDACIONALISMO NAS CONCEPÇÕES DE ORDENAMENTO JURÍDICO ENQUANTO SISTEMA PIRAMIDAL E HIERARQUIZADO}

\subsection{Os conceitos de ordenamento predominantes na Teoria do Direito}

A concepção mais comum de sistema que vem sendo adotado pela Teoria do Direito advém, como ensina Canaris (2002, p. 10-11), de uma noção clássica kantiana que o caracteriza como "a unidade sob uma ideia de conhecimentos variados". Por isso, os mais corriqueiros conceitos de sistema jurídico giram em torno dessa ideia de unidade, como "concatenação interior que lida todos os institutos jurídicos e as regras de Direito numa grande unidade"; uma "unidade totalmente coordenada" ou, ainda, "ordenação segundo um ponto de vista unitário". Em razão disso, Canaris (2002, p.23) explica que "o papel do conceito de sistema é, no entanto, como se volta a frisar, o de traduzir e realizar a adequação valorativa e a unidade interior da ordem jurídica".

O conceito mais difundido na doutrina brasileira de sistema jurídico é erigido com base nas lições de Hans Kelsen e Norberto Bobbio e não foge desse padrão clássico kantiano descrito por Canaris. Não traz, no entanto, a ideia de adequação valorativa, dando ênfase à questão da unidade e coerência sob um formalismo jurídico há muito ligado ao positivismo ${ }^{1}$. Tem-se que Kelsen destaca que o sistema jurídico "é uma construção escalonada de diferentes camadas ou níveis de normas jurídicas". Também se vale da concepção de unidade para caracterizar o ordenamento enquanto sistema, a qual "é produto da conexão de dependência que resulta do fato de a validade de uma norma, que foi produzida de acordo com outra norma, se apoiar sobre essa outra norma, cuja produção, por sua vez, é determinada por outra; e assim por diante, até abicar finalmente na norma fundamental - pressuposta" (KELSEN, 1999, p. 247). A unidade do ordenamento jurídico consiste, portanto, na possibilidade de recondução de toda e qualquer norma a uma única, hipotética e fundamental, mediante a análise da cadeia de delegações de poderes normativos, desde esse ápice único.

Essa conexão entre uma norma e outra não é por seu conteúdo, mas por laços formais consistentes em uma sucessiva delegação de competências das inúmeras autoridades que põem as

\footnotetext{
${ }^{1}$ Nesse tocante é preciso, porém, destacar o alerta muito bem realizado por Fernando Leal (LEAL, 2014 , p. 245 268), no sentido de que, muitas vezes no Brasil, se realiza uma incorreta compreensão da dimensão formalista e positivista em Kelsen, que são traduzidos em um sentido pejorativo de legalismo e uma compreensão dedutivista do raciocínio jurídico, em especial na aplicação das regras por mera subsunção. Como destaca, positivismo é usado como sinônimo de formalismo e legalismo. No que toca à caracterização formalista, o adjetivo positivista é aplicado para designar uma teoria do raciocínio jurídico que reduz a aplicação do direito à subsunção neutra de fatos ao predicado fático de prescrições legislativas". Procurar-se-á, pois, a colocação precisa do positivismo o do formalismo, sem recair do legalismo e no dedutivismo, que, de fato, não traduzem acertadamente a teoria kelseniana, influente em Bobbio, para explicar o ordenamento jurídico. Busca-se expor suas ideias no contexto metodológico que propõe para investigar o Direito como fenômeno sociocultural.
} 
normas no sistema. A posição hierárquica, assim, é determinada por um critério formal (autoridade legiferante), independentemente de seu conteúdo.

Essa unidade conseguida por critério formal classifica o ordenamento jurídico como um sistema dinâmico, o qual se opõe ao sistema estático em que essa reinserção de um preceito em outro se dá pelo conteúdo, tendo no ápice princípios máximos ou gerais. Com efeito, Bobbio é expresso em dizer que o ordenamento é um sistema dinâmico, no "qual as normas que o compõem derivam umas das outras através de sucessivas delegações de poder, isto é, não através do seu conteúdo, mas através da autoridade que as colocou, até chegar à autoridade suprema que não tem nenhuma outra acima de si". Por esse motivo, o autor italiano explica que "a relação entre as várias normas é, nesse tipo de ordenamento normativo, não material, mas formal" (BOBBIO, 1999, p. 72).

Esse tipo de sistema dinâmico é diferente do sistema estático, como, por exemplo, o de Leibniz, bem exposto por Perez Bermejo (2006, p.44). Nele, parte-se de uma noção geral de justiça (entendida em termos de busca do bem comum), posta como preceito da mais elevada virtude material, em razão de seu conteúdo melhor traduzir racionalmente o princípio que deve inspirar a conduta dos indivíduos. Não se vê relevância na autoridade que o estatui, porque ele se impõe por sua racionalidade reta de bem captar e expressar o ideal de justiça em termos gerais. Desse preceito mais amplo e geral, desenvolvem-se três princípios mais específicos: o honeste vivere, o neminem laedere e o suum cuique tribuere. O primeiro (honeste vivere) é apontado como princípio universalmente aplicado ao Direito ante a exigência de uma virtude moral no comportamento. $\mathrm{O}$ segundo e o terceiro seriam princípios particulares. $\mathrm{O}$ neminem laedere rege as relações privadas, resumindo-se à proibição de praticar dano a terceiro. O suum cuique tribuere rege as relações públicas, não só vedando danos a terceiros como também impondo o incremento da felicidade de todos. Desses preceitos fundamentais, fazem-se inferências lógicas dedutivas em razão do conteúdo, não sendo determinante se realizada por jurista ou legislador, porquanto o que importa é o conteúdo deduzido dos preceitos mais gerais.

Como se pode perceber, o sistema estático de Leibniz impõe uma submissão do legislador a preceitos gerais e concepções metafísicas de justiça, todos obtidos por escrutínio racional. Contraria, dessa forma, a centralidade jurídica no Estado, a concepção de preponderância do papel do legislador democraticamente eleito, dentro de um modelo jurídico fundado em uma Constituição, e se opõe ao formalismo científico que renega, no Direito, a busca de elementos etéreos e abstratos, como a ideia de justiça. O tipo dinâmico de sistema, pois, se adequa muito melhor ao positivismo e ao formalismo jurídico, bem como ao modelo de estado de Direito conhecido desde o século XVIII.

É certo que o modelo kelseniano de relações de delegação sofreu precisas críticas de Joseph Raz, que sofistica, mas não elide, o modelo de sistema hierarquizado. Propõe, no entanto, uma figura em árvore, que, na sua concepção, melhor explica a complexidade das inúmeras relações das partes do ordenamento jurídico, que é obscurecida ou simplesmente ignorada pela figuração em pirâmide.

A contribuição de Raz, nesse específico ponto, se destaca em individuar que a delegação de poderes de criação normativa de uma camada para outra se dá por normas específicas, identificadas em razão desse fim, distinta da norma de conduta. É uma proposta diferente, porque Kelsen entende que essa delegação está contida na norma de conduta. Para ele, as normas de competência integram as normas de condutas, havendo uma relação direta entre uma norma inferior e outra superior. Por outro lado, Raz entende que as normas de competências são espécies autônomas de normas. Não são apenas partes integrantes das normas de condutas, pelo que a relação entre as normas de conduta dos vários níveis não se operam diretamente, mas apenas por meio de uma norma de competência.

Conforme explica Raz (2012, p. 152), Kelsen propõe um grupo de relações genéticas lineares, ou seja, de uma norma autorizando, via delegação de poderes a autoridades específicas, 
a criação de outra. Tais relações genéticas se verificam entre partes específicas das normas de conduta. Raz, porém, entende, com esteio nas lições de Herbert Hart, que as delegações são realizadas por normas autônomas, de competência, havendo, pois, não somente uma linha única de relações genéticas, mas uma gama maior delas, permitindo mesmo entrecruzamento de cadeias hierárquicas, porquanto poderá haver normas de competências pertencentes a mais de uma cadeia de relação hierárquica. Substitui-se, como dito, a rígida e bem aparada figura piramidal por uma em árvore, com ramos entrelaçados, porquanto há uma variedade maior de relações hierárquicas.

Herbert Hart (2009, p. 122), de fato, vislumbra dois tipos de normas, as primárias que prescrevem condutas e as secundárias, que lhes são superiores, porque disciplinam as normas primárias, determinando como podem ser produzidas, introduzidas no sistema, eliminadas e alteradas. Em suas próprias palavras: "pode-se dizer que todas as normas secundárias se situam num nível diferente daquele das normas primárias, pois versam todas sobre essas; isto é, enquanto as normas primárias dizem respeito a atos que os indivíduos devem ou não devem praticar, todas normas secundárias se referem às próprias normas primárias".

Ainda assim, algumas características fundamentais de Kelsen persistem nas ideias de Raz e mesmo Hart, porquanto ainda mantida a hierárquica normativa (como visto Hart alude que as normas secundárias são superiores às primárias) e a validade de uma norma ser obtida em outra. A natureza formal, hierarquizada e dinâmica de sistema jurídico também se mantém sem maiores dificuldades. Não há qualquer cogitação de ordem conteudística ou material entre as partes.

Ao lado da unidade, entendida nesses termos de encadeamento hierárquico, há a coerência como característica definidora do sistema jurídico. Aqui, o formalismo também é o modo pelo qual se a compreende. Bobbio fala do ordenamento jurídico como sistema, porque suas partes guardam harmonia na interação entre si. Escreve que "sistema equivale à validade do princípio que exclui a incompatibilidade das normas. Se num ordenamento vêm a existir normas incompatíveis, uma das duas ou ambas devem ser eliminadas. Se isso é verdade, quer dizer que as normas de um ordenamento têm um certo relacionamento entre si, e esse relacionamento é o relacionamento de compatibilidade, que implica a exclusão da incompatibilidade" (BOBBIO, 1999, p.80).

As partes desse sistema são normas, que possuem a particular estrutura "Se f, então Sc". Nela, "f" e "c" são duas enunciações, a primeira como descritor de fatos (hipótese de incidência) - os quais uma vez verificados no mundo empírico ocasionam a incidência da norma de maneira automática e infalível -, e a outra como consequente normativo na forma de uma relação jurídica. $\mathrm{O}$ "S" é o modal deôntico (obrigatório, proibido ou permitido), expresso de maneira cogente de tudo ou nada, sem comportar grau de realização: ou a norma se aplica, ou ela não é vigente. A incompatibilidade surge quando duas normas distintas atribuem consequências incompatíveis entre si para os mesmos fatos descritos em suas hipóteses de incidência. Daí, emergem critérios para salvaguardar a coerência, solucionando as antinomias. São os conhecidos critérios da especialidade, hierarquia e temporal.

Também é controlado o ingresso das normas no ordenamento, pelo que obedece a critérios previamente estabelecidos, normalmente mediante processo do legislativo ou ato normativo de outra autoridade previamente definida. $\mathrm{O}$ critério de ingresso é definido pela norma de reconhecimento, na proposta de Hart, e pela norma hipotética fundamental de Kelsen.

A despeito de distinções identificadas nas propostas desses autores, elas convergem em pontos importantes que os inserem no mesmo gênero de sistema fundacionalista, sobretudo em função do papel desempenhado neles pelo formalismo, conforme se passa a expor. 


\subsection{As características formalistas e fundacionalista dos modelos de sistema jurídico de Kelsen/Bobbio e Hart/Raz}

Os modelos de sistema jurídico de Kelsen, Bobbio, Raz e Hart são erigidos, como visto, dentro do mesmo parâmetro do Direito, com variações de ênfase em um ou outro autor. No entanto, é possível detectar em todos eles o entrelaçamento entre o positivismo e o formalismo, que muito bem moldaram o pensamento jurídico do século XX. Menezes Cordeiro, na introdução portuguesa da obra de Canaris, ensina que o "formalismo e o positivismo, apresentados respectivamente, como o predomínio de estruturas gnosiológicas de tipo neo-kantiano e como recusa, na Ciência do Direito, de considerações não estritamente jurídico-positivas, constituem o grande lastro metodológico do século vinte" (CANARIS, 2002, XV-XVI).

De fato, o positivismo descarta justamente a necessidade de busca de um conteúdo específico para o Direito, impondo sua distinção para a moral não pela matéria, mas pela sanção institucionalizada. Buscam-se apenas as concepções necessárias para articulação dos inúmeros elementos das normas postas pelo Estado. Embora não se confunda, entrelaça-se com o formalismo, que traz um recorte e ressignificação da realidade para inseri-la no sistema segundo estruturas formais. Por isso, Bobbio (2006, p. 146) muito bem destaca que essas "duas doutrinas não se identificam nem são estranhas uma à outra; diremos antes que são duas doutrinas diferentes que possuem, todavia, muitos pontos em comum e que se acompanham em seu desenvolvimento histórico". Nesse contexto, expõe que "a concepção formal de direito define, portanto, o direito exclusivamente em função da sua estrutura formal, prescindindo completamente do seu conteúdo - isto é, considera como o direito se produz não o que ele estabelece" (BOBBIO, 2006, p.145).

É justamente em função do formalismo que todo o material jurídico é traduzido em termos normativos com a estrutura "Se f, então Sc". O ordenamento jurídico, por via de consequência, é formado apenas e tão somente por elementos com esse caráter normativo formalista. Tudo que será tratado pelo Direito é apreendido após um filtro formalista, segundo categorias próprias do Direito positivo. Por exemplo, o casamento, a despeito de sua complexa natureza em função de sua dimensão social, religiosa, íntima e pessoal, é tomado na forma de um contrato bilateral que os nubentes pactuam, e que possui, como todo e qualquer contrato, forma, objeto, direitos, obrigações, início e término. Tudo da complexa relação matrimonial que não possa ser traduzido nesses termos, é ignorado pelo Direito, em uma acepção positivista e formalista.

O formalismo jurídico é ladeado pelo formalismo científico. Bobbio (2006, p. 221) mais uma vez bem aponta que "tem uma concepção formalista de ciência jurídica, visto que na interpretação dá absoluta prevalência às formas, isto é, aos conceitos jurídicos abstratos e às deduções puramente lógicas que se possam fazer com base neles, com prejuízo da realidade social que se encontra por trás de tais formas” (BOBBIO, 2006, p. 221). Em igual sentido, há uma relação com o formalismo ético, que compreende que a ação devida e ajustada é apenas e tão somente aquela concordante com a lei, independentemente de qualquer conteúdo material, deontológico ou axiológico.

Essas características estão presentes claramente na teoria do ordenamento jurídico enquanto sistema, no entendimento de Kelsen, Bobbio, Raz e mesmo em Hart. Por isso, possível enquadra-los, todos, em um mesmo gênero de sistema que Bermejo denomina de fundacionalista, justamente porque são hierárquicos, axiomáticos e fechados, em maior ou menor grau.

Os sistemas fundacionalista são hierárquicos justamente porque suas partes são distribuídas em planos ou estratos, em que os inferiores são derivações formais dos superiores. Cada parte integrante é tomada como peça fixa, rígida e pré-definido com espaço específico e imutável em um escalão que se relaciona com o superior e o inferior por uma ou várias linhas unidirecionais de hierarquia. A relação entre as peças é assimétrica, sempre no mesmo sentido:

Revista de Direito Brasileira | São Paulo, SP | v. 18 | n. 7 | p. 149 - 172 | Set./Dez. 2017 
das camadas superiores para as inferiores, por meio de uma lógica formal dedutiva. Nas palavras de Bermejo (2006, p. 82), “el sistema jurídico consta así de una base fundamental de normas 'formuladas', o enunciadas por alguna autoridad o fuente del derecho reconocida, y de un conjunto de normas 'derivadas' cuya pertenencia al sistema depende, como condición necesaria y suficiente, de ser lógicamente deducibles de las primeras".

O sistema fundacionalista é axiomático porque as camadas mais altas são postas sem maiores justificações, apresentando-se como verdades auto-evidentes. São esses axiomas que fixam "algoritmos" formais reguladores da entrada e saída das partes no conjunto sistemático. Escreve Bermejo(2006, p.90):

En todo caso, con independencia de la cantidad y naturaleza de los axiomas, pude concluirse que, en las versiones positivistas contemporáneas del sistema jurídico, se abriga la percepción de que el sistema se ordena desde un nivel básico o fundamentador. Este nivel se compone de una serie de normas independientes, originarias, no derivadas, y que se asumen como puntos fijos e intangibles del sistema jurídico. El resto del sistema jurídico ha de comprenderse así como una inferencia de la base axiomática, y ha de poder mostrar algún tipo de conexión lógica, directa o indirecta, con algún elemento de la misma.

O caráter axiomático da regra de reconhecimento de Hart é evidenciada quando ele escreve sobre o fundamento de validade de regra de reconhecimento, ao que defende não poder "surgir uma pergunta desse tipo sobre a validade da própria norma de reconhecimento que provê os critérios; esta não é válida nem inválida, mas seu uso para esse fim é simplesmente aceito e apropriado" (HART, 2009, p. 140). Percebe-se, é certo, um abrandamento, quando indica que a regra de conhecimento é algo complexo identificado por um conjunto de elementos, como opiniões de autoridade, textos escritos e decisões de tribunais, pelo que não teria sentido essa indagação para um espectador do ponto de vista interno (de quem integra e aceita a ordem jurídica), mas é atestada empiricamente por um observador externo (aquele que não integra nem se sente obrigado por aquele ordenamento). Assim, a razão de ser da regra de reconhecimento é essa sua indistinta aceitação verificada em um conjunto de fatos.

Por fim, o caráter fechado do ordenamento jurídico é definido por Bermejo, porque se apresenta como um sistema delimitado, finito, com limites precisos e elementos enumeráveis. Como explica: "Decir sistema cerrado es decir sistema delimitado, lo que implica la posibilidad de precisar los elementos de los que se compone el sistema sin necesitar criterios externos o préstamos provenientes de otros sistemas" (BERMEJO, 2006, p. 90). Como se lê, o conceito de sistema fechado em Bermejo é bem específico, porque definido como aquele que possui critérios próprios para definir o que lhe pertence ou não lhe pertence, para estabelecer aquilo que pode ingressar ou não no sistema e passar a fazer parte dele. Esses critérios próprios para definição do que pode integrar o sistema é chamado pelo autor genericamente de algoritmo, os quais "recogen la exigencias de acceso al sistema, el sello o salvoconducto que han de representar los posibles candidatos al mismo para ser admitido dentro del sistema, así como los argumentos que justifican su rechazo" (BERMEJO, 2006, p.91). Com os algoritmos, define-se o próprio sistema, mudandose os algoritmos, muda-se o sistema, porque altera-se o que dele faz parte ou não faz parte. Com eles, também é possível separar com clareza o que integra e o que não integra o sistema, bem como o momento, o átimo temporal, a partir do qual ingressa no sistema ou o deixa.

Nos sistemas fundacionalista, tais algoritmos são, via de regra, formais. Os modelos positivistas de sistema, no entanto, variam nesse tocante, porquanto em algumas propostas (como a de Hart) o momento de ingresso e saída de uma parte no sistema nem sempre se dá de maneira clara e bem definida em um dado momento. 


\subsection{Alf Ross e o abrandamento das características fundacionalistas ainda persistentes: necessidade de ir além}

Se em Hart há um abrandamento dessas características com sua apropriada concepção de regra de reconhecimento a partir de uma perspectiva social, em Ross essas duas características (axiomático e fechado) são quase que elididas por completo, ainda que persistam em um grau menor, mantendo, no entanto, seu caráter hierárquico intocado. Com efeito, conquanto representante do realismo escandinavo, o pensamento de Alf Ross, assim como o próprio realismo, pode ser entendido como um modo de positivismo, em um sentido mais amplo, conforme propõe Bobbio (2006, p.145):

A definição do positivismo (em sentido estrito) e a do realismo jurídico, em sua diversidade, têm um elemento em comum: são definições anti-ideológicas, definições que não fazem referência a valores ou fins que seriam próprios do direito. Deste ponto de vista, ambas podem ser qualificadas como definições positivistas (em sentido lato), em contraposição às definições ideológicas ou valorativas, que (sempre em sentido lato) podem ser qualificadas como justnaturalistas"

Em Ross, a figura em árvore hierarquizada persiste, mas exposta de uma maneira invertida, ou seja, com o cume para baixo e não para cima, como na proposta tradicional de Kelsen e Bobbio. É o que se infere das lições do autor:

O ponto de que partimos é a hipótese de que um sistema de normas será vigente se for capaz de servir como um esquema interpretativo de um conjunto correspondente de ações sociais, de maneira que se torne possível para nós, compreender esse conjunto de ações como um todo coerente de significado e motivação e, dentro de certos limites, predizê-la. Esta capacidade do sistema se baseia no fato de as normas serem efetivamente acatadas porque são sentidas como socialmente obrigatórias. (ROSS, 2000, p. 59).

Como se lê, Ross exige para a vigência das normas do sistema jurídico a confirmação por um determinado fato social, que a reconheça como vinculante. Ele indaga quais seriam esses fatos sociais, ao que responde que são ações humanas reguladas pelas normas jurídicas, entendidas estas, por sua vez, como normas que regulam o exercício da força pelos tribunais. Assim, conclui que são as decisões dos tribunais tomadas em observância de uma determinada norma que determinam sua vigência. "Em conformidade com isso, um ordenamento jurídico nacional, considerado como um sistema vigente de normas, pode ser definido como o conjunto de normas que efetivamente operam na mente do juiz, porque ele as sente como socialmente obrigatórias e por isso as acatas" (ROSS, 2000, p. 59). É por isso que sua figuração piramidal é invertida, porque as leis, os regulamentos e mesmo as normas constitucionais colhem seu fundamento de validade nas decisões judiciais que são em maior número do que aquelas.

Ele também distingue, tal qual Hart e Raz, as normas em normas de conduta e normas de competência. As primeiras prescrevem uma determinada e específica linha de ação. As segundas estatuem competências, ou seja, estabelecem o modo pelo qual se produzem normas de conduta. Há, então, uma relação de hierarquia e reinserção similar á proposta de Raz em sofisticação à proposta de Kelsen.

Acontece que todos esses modelos de sistema jurídico, classificados genericamente como clássicos, não se mostram inteiramente adequados para explicar o fenômeno sistêmico no Direito. Rodrigo Azevedo Greco, em magnífica obra sobre o assunto, recorre a lições de Mário Losano para demonstrá-la. A principal falha reside na proposta de seu caráter fechado, que deixa à margem de suas considerações vários aspectos do Direito. Nesse tocante, "se limita ao 
condicionamento da validade do sistema jurídico à sua eficácia global, não sendo objeto de análise nem a relação entre a estrutura do sistema jurídico e sua capacidade de atingir os fins a que ele se propõe nem os efeitos das transformações sociais sobre a estrutura do sistema jurídico" (GRECO, 2015, p. 30). Por isso, segundo o autor, Mario Losano vaticina que a figura da pirâmide, quando muito, explica uma pequena realidade do sistema jurídico, deixando de fora uma grande quantidade de elementos, normalmente aquilo que há de mais inovador e revelador do Direito. Traduz uma cegueira formalista incapaz de lidar com a complexidade da realidade regulada e efetivamente tratada pelo sistema jurídico. É, portanto, uma ilusão, um vetusto e mal alinhavado desenho do sistema jurídico, pelo que deve ser abandonado.

Ao se tentar empregar tal modelo aos precedentes judiciais, essa incapacidade da tradicional visão do sistema jurídico mostra de maneira ainda mais marcante suas deficiências, justamente por serem ricos elementos do Direito que são desprezados pela pirâmide axiomática fechada. É o que se passa a demonstrar.

\section{OS PRECEDENTES JUDICIAIS NA PIRÂMIDE AXIOMÁTICA FECHADA: REGISTRO DE UMA INCOMPATIBILIDADE}

A inadequação dos precedentes judiciais à teoria clássica do ordenamento jurídico decorre da incompatibilidade deles aos elementos característicos explicados acima. Com efeito, os precedentes judiciais são refratários ao positivismo normativista, ao formalismo, à unidade hierarquizada e a uma coerência obtida apenas por meio dos três critérios de solução de antinomias.

Acontece, no entanto, que forçosamente se aplica essa teoria clássica aos precedentes, o que se dá mediante a mutilação de suas caraterísticas definidoras, reduzindo-os a uma pobre estrutura formal. Recorre-se, para tanto, ao positivismo e ao formalismo jurídico. Releva-se o conteúdo da decisão judicial tomada, dando-se ênfase a aspectos formais como o tribunal que o emite e o tipo de processo ou procedimento em que se proferiu a decisão. Essa é a dimensão positivista. Por outro lado, o formalismo impõe a tradução em termos sintéticos e formais do complexo trabalho hermenêutico operado de maneira dialética pelo julgador. Reduz-se o precedente a uma norma com a estrutura "Se f, então Sc", sem qualquer espaço para avaliação de seu conteúdo, coerência ou integridade. Esse é o aspecto formalista.

Essa é a proposta explícita de Pedro Henrique Veiga Chrismann (2016) ao balizar a necessidade de um estudo mais acurado dos precedentes em torno do seguinte: "Pode-se, ou deveria ser possível de, extrair uma norma de estrutura semelhante a de uma regra de um julgado. Essa norma deveria ditar como juízes ou tribunais podem ou devem se comportar no futuro diante um caso de propriedades semelhantes".

Kelsen propõe igualmente compreensão formalista e positivista. Em sua Teoria Geral do Direito e do Estado (KELSEN, 2005, 216), ele também lida com o conceito de precedente, que entende como um caráter a ser assumido por uma sentença ao admitir que "decisão judicial também pode criar uma norma geral" Para ele,

[...]a decisão de um tribunal num caso concreto assume o caráter de precedente obrigatório para as decisões futuras de todos os casos similares por meio de uma generalização da norma individual criada pela primeira decisão. É a força da obrigatoriedade da norma geral assim obtida que é a essência de um chamado precedente.

Destaque-se, então, o formalismo e o positivismo jurídicos atuando no conceito: tudo aquilo que foi tratado e discutido no processo, todos os argumentos e contra-argumentos, a fundamentação da decisão, sua adequação principiológica e axiológica com outras disposições do 
sistema, tudo, deve ser reduzido à simplória estrutura "Se f, então Sc". O que não for necessário para essa estrutura não ingressa no sistema jurídico segundo a concepção clássica. Por essa razão, ensina Kelsen que "dentro de tal sistema jurídico, os tribunais são órgãos legislativos exatamente no mesmo sentido em que o órgão é chamado de legislativo no sentido mais restrito do termo. Os tribunais são criadores de normas jurídicas gerais" (KELSEN, 2005, 216).

Essa equiparação entre juiz e legislador não é levada em termos absolutos nem mesmo por Kelsen, porque assemelha a criação do precedente não a um processo legislativo, como seria lícito se imaginar. Indica, por outro lado, uma equiparação ao costume jurígeno, reconhecido assim pelo sistema, pois, segundo expõe, "esse tipo de criação de Direito deve ser claramente distinguido da criação de normas gerais através da prática permanente dos tribunais, i.e., através do costume" (KELSEN, 2005, p. 217).

Essa indeterminação kelseniana gera um problema para a unidade do sistema jurídico, porque não detalha a posição hierárquica do juiz na pirâmide normativa, quando ele cria precedentes. Ao tratar do assunto, põe o juiz na camada mais abaixo, porque recebe o poder de emitir normas individuais e concretas (das quais se infere a geral e abstrata que forma o precedente) em razão de uma série sucessiva de delegações, que perpassa desde as normas constitucionais às legislativas.

É possível postular que o juiz ocuparia o mesmo estrato hierárquico do legislador, porque Kelsen os equipara, mas não é inteiramente adequado dizer isso, além do que não resolveria a questão da hierarquização dos precedentes entre si. A delegação não é feita pela norma geral e abstrata que compõe o precedente, mas por outra norma do sistema. Não haveria, então, uma delegação direta de poderes por um precedente superior para os tribunais inferiores. Um precedente não colhe seu fundamento de validade em outro precedente, mas em uma norma legislativa ou constitucional que confere o poder jurisdicional ao juiz ou tribunal.

A despeito dessas dificuldades, a doutrina nacional apressa-se em tomar, sem reflexão mais detida, o precedente judicial nesses termos positivistas e formalistas, mesmo declarando buscar se inspirar em concepções pós-positivista. Propõe-se, sem se cogitar sobre as outras opções teoricamente existentes, que precedente, ou ao menos sua ratio decidendi, é, tal qual propõe Kelsen, uma norma geral e abstrata retirada da decisão judicial. Por via de consequência, a posição hierárquica do precedente, necessário para a unidade do sistema, é apresentada de maneira simplória. Ravi Peixoto (2015, p. 179) propõe assim a determinação da hierarquia do precedente:

Se o precedente é norma, incumbe fixar seu nível hierárquico, que, geralmente, irá depender do nível da questão de direito solucionada. Se ela possuir natureza constitucional, o precedente terá status constitucional, já se possuir natureza infraconstitucional, terá status de norma infraconstitucional. A constatação é relevante para se verificar de que forma o Poder Legislativo e o Poder Executivo poderão ir de encontro a ele, já que, no caso de norma de precedente infraconstitucional, ele poderá ser revogado por lei de igual hierarquia. Porém, um precedente de natureza constitucional só poderá ser revogado por meio de uma emenda constitucional.

Embora o autor parta de uma constatação verdadeira, concernente ao modo de superação de um precedente pelo Legislativo e pelo Executivo, chega a uma conclusão falsa, pois isso não é critério para determinar seu status, mas apenas e tão somente critério para assegurar a coerência. O erro principal reside no fato de que, no sistema dinâmico, conforme exposto, a hierarquia é critério para assegurar sua unidade, sendo cada escalão determinado pela autoridade que a põe e não pelo conteúdo que eventualmente possui. Vale relembrar com Kelsen (1999, p.278) que "uma norma jurídica não vale porque tem um determinado conteúdo, quer dizer, porque o seu conteúdo pode ser deduzido pela via de um raciocínio lógico uma norma fundamental 
pressuposta, mas porque é criada por uma forma determinada - em última análise, por uma forma fixada por uma norma fundamental pressuposta".

Portanto, o conteúdo não determina o nível hierárquico de uma norma. Quem o determina é a autoridade que a produziu, dentro do conjunto escalonado de delegações de competências. O fato de uma norma constitucional, legislativa ou regulamentar poder superar precedente com conteúdo a eles relacionados diz respeito à questão de coerência do sistema e não de sua unidade.

O fato, então, de um precedente sobre matéria constitucional só poder ser alterado, no plano normativo, por uma emenda constitucional, não lhe garante hierarquia constitucional, pois somente normas do poder constituinte originário ou derivado (em processo de emenda) possuem tal capacidade. Essa relação entre precedente e emenda constitucional se refere simplesmente à salvaguarda da coerência do ordenamento jurídico, de modo a impedir a coexistência de disposições incompatíveis a respeito de matéria que só o poder constituinte derivado pode dispor, e não à definição do escalão normativo relacionado a sua unidade.

Não se pode dizer, também, que um juiz tem o seu poder jurisdicional de emitir precedentes em razão de uma delegação de poder do Tribunal que integra. Nem mesmo se poder dizer que a apreciação, por um tribunal local, sobre questões constitucionais se dê nos moldes de uma delegação oriunda do Supremo Tribunal Federal. Para haver hierarquia, deverá haver essa série de delegações de um tribunal para outro. Acontece que todo e qualquer magistrado, independentemente do tribunal que integra ou de seu nível na pirâmide judiciária, retira seus poderes da mesma fonte normativa: a Constituição Federal. É dela que provém a delegação de poderes para que cada magistrado e tribunal possa proferir julgamentos e, por via de consequência, produzir precedentes.

Nesse tocante, o positivismo hartiano, que é refletido em Raz e Ross, ao adotarem a dicotomia norma primária/secundária, é suficiente para solapar uma hierarquia entre precedentes nos moldes propostos por Kelsen e Bobbio para as normas jurídicas em geral, porquanto bem evidencia que todos os tribunais, de maneira uniforme, retiram o fundamento de validade de seus precedentes da norma que lhe confere o poder jurisdicional. Como explica, "a norma que conferir jurisdição será também uma norma de reconhecimento, que identificará as normas primárias por meio dos julgamentos dos tribunais, e esses julgamentos se tornarão 'fonte' do Direito" (HART, 2009, p. 126).

Assim, todos os precedentes colhem seu fundamento de validade diretamente na Constituição Federal, recebendo, todos, delegação de poder da mesma autoridade, o poder constituinte. Por esse motivo, não se pode falar de distribuição deles em planos ou escalões distintos, porquanto não há a sucessiva delegação de poderes de uma autoridade para outra. A delegação é única: do poder constituinte para todos os juízes e tribunais. A hierarquia verificável é do tribunal emissor, mas como um tribunal não delega poderes para outro que lhe é inferior, não se pode falar de hierarquia entre seus julgados. Há, é certo, uma necessidade de coerência entre eles, e para realização dessa coerência (característica distinta da unidade, vale lembrar), o nível hierárquico de cada corte influencia, mas não para determinar uma apriorística superioridade, porquanto incorrerão outros elementos, como, por exemplo, o tipo de processo em que foi emitido, uma maior integridade de um julgado, ainda que inferior, entre outros fatores, como a abrangência e precisão da motivação.

Vê-se, pois, que o modelo piramidal e hierarquizado de Kelsen e Bobbio não é adequado para estruturação dos precedentes, pois sua ideia específica de unidade enquanto sucessiva delegação de poderes não é verificada nos precedentes, conforme já evidenciado pelas ideias de Hart. É preciso, pois, abandonar essa proposta.

Melhor sorte não tem a outra característica que Kelsen e Bobbio atribuem a seu modelo de ordenamento: a coerência normativa. Como exposto acima, ela é assegurada pelos critérios de solução de antinomias, hierárquico, temporal e da especialidade. Mesmo a doutrina estrangeira, 
propõe esses critérios como válidos para assegurar a coerência entre precedentes. É o que propõe, por exemplo, Robert Alexy, ao examinar o assunto em trabalho específico sobre o tema:

There are, as mentioned in the answer in Section II.2. above, procedures to prevent the development of conflicts of precedents. But in case a conflict still arises, there are no firm rules. It could be said that the generally recognized rules of posteriority, speciality and superiority (compare Alexy and Drier, 1991, p. 99) have a certain prima facie force not only on statutes but also on precedents. Yet, in contrast to statutes, precedents are always capable of being subverted by a change in the balance of substantive reasons on a given point. (SUMMERS, 1997, p. 59)

Os critérios que o autor afirma já haver mencionado são processuais, de controle mediante recurso e a existência de corte superior com função de uniformização de jurisprudencial, como, por exemplo, o Superior Tribunal de Justiça. Contudo, ante a falha desses critérios processuais, insiste nos critérios clássicos de resolução de antinomias legislativas, demonstrados aqui incabíveis. É certo que vislumbra o critério próprio concernente aos precedentes, que é a alteração de circunstâncias analisadas, mas não o desenvolve adequadamente nem explora outros. Acontece que trais critérios não são suficientes para solucionar o conflito entre precedentes.

Não se pode falar, por exemplo, que um precedente posterior necessariamente superará um anterior com ele incompatível apenas e tão somente por essa razão. Um precedente há muito arraigado na tradição jurídica e judiciária, que tenha gerado jurisprudência e adesão de outros tribunais, definido práticas institucionais e delineado institutos jurídicos não pode ser considerado plenamente superado só porque houve um posterior que a ele se opõe. Em verdade, é muito comum que uma firme linha jurisprudencial se imponha mesmo diante de uma pontual divergência ainda que no mesmo tribunal. É certo que tais precedentes podem ser superados, mas demandam razões adicionais para tanto, como mudança do quadro jurídico ou social, modificação de valores, evolução dos fatos, tudo a ser exposto por uma necessária e bem alinhavada fundamentação que enfrente francamente a superação ou o desafio jurisprudencial. Caso contrário, como dito, a tendência é o precedente mais antigo e arraigado se reafirmar em situações posteriores. Doutrina estrangeira, denomina tal sorte de julgados de super-precedentes ${ }^{2}$.

É possível exemplificar isso na análise da linha de precedentes do Supremo Tribunal Federal a respeito do descabimento de Recurso Extraordinário por ofensa reflexa à Constituição Federal. O entendimento de tão firme foi enunciado na súmula 280 daquela corte, no sentido de que "por ofensa a direito local não cabe recurso extraordinário".

Vários julgados foram proferidos nesse sentido para não conhecer recursos oriundos do Rio Grande do Sul, em que se alegava o direito de servidores públicos do Executivo estadual terem reajustados mensalmente o valor de seus vales-refeições. $\mathrm{O}$ tribunal entendia haver apenas ofensa à lei local que determinava esse reajuste. A despeito disso, em 2008, sob a relatoria do Min. Marco Aurélio Melo, o RE 428.991 foi conhecido e provido, sob o entendimento de que caberia, sim, recurso extraordinária para análise de ofensa indireta à Constituição Federal.

Entretanto, nem mesmo o Tribunal de Justiça do Rio Grande do Sul acompanhou esse novo precedente, pois, por seus julgados, entendeu que representava entendimento isolado,

\footnotetext{
${ }^{2}$ A respeito do assunto, leciona Michael Gerhardt: "Super precedents are not unique to the courts, but rather are constitutional decisions in which public institutions have heavily invested, repeatedly relied, and consistently approved over significant periods of time. These are decisions which have been so repeatedly and widely cited for so long that their meaning and value have increased to the point of being secured by enduring networks. They are deeply and irrevocably embedded into our culture and national consciousness, so much so that it seem in-American to attack, much less to formally reconsider them. These decision are the clearest instances in which the institutional values promoted by fidelity to precedent - consistency, stability, predictability and social reliance - are compelling". (GERHARDT, 2008. p. 178)
}

Revista de Direito Brasileira | São Paulo, SP | v. 18 | n. 7 | p. 149 - 172 | Set./Dez. 2017 
proferido por turma que não possuía composição completa por ocasião do julgamento, não tendo a fundamentação indicado outras razões para abandono a linha jurisprudencial anterior.

O Supremo Tribunal Federal reafirmou seus julgamentos mais antigos no RE $607.607^{3}$, entendendo insuficiente a mera superveniência de um precedente posterior para ocasionar o overruling. Fosse uma norma legislativa, as cogitações sobre o arraigamento ou acerto da lei anterior, ou a debilidade do quórum de votação no processo legislativo da posterior, seriam irrelevantes, dado o caráter autônomo e absoluto do critério temporal: lei posterior revoga anterior que lhe é contrária a despeito das qualidades ou quórum desta última.

Esse mesmo exemplo demonstra que o critério hierárquico também não é suficiente para se impor autonomamente, pois o Tribunal de Justiça do Rio Grande do Sul desafiou o julgado superior e mais recente apontando sua incoerência com uma linha jurisprudencial mais arraigada. Não se tratou se um distinguish, em que se demonstra uma situação fática mais específica a autorizar a não aplicação do precedente. Ao contrário, indicou-se claramente ser caso semelhante, mas, ainda assim, apontaram-se critérios outros que justificaram a desobediência hierárquica ${ }^{4}$. Jamais um legislador, nos termos da teoria clássica do ordenamento jurídico, poderá realizar esse frontal desafio hierárquico.

Por fim, a possibilidade de existirem critérios diversos para aquilatar a força de um precedente ante um conflito também infirma a autonomia e suficiência do critério da especialidade. Um precedente mais específico, mas que seja mal fundamentado, julgado por maioria em processo sem força vinculante e constantemente contestado pela doutrina e por outros julgados deve ceder a um mais genérico, que, ao contrário, seja bem fundamentado, proferido por unanimidade e com força vinculante, recebendo apoio de outras fontes jurídicas.

Portanto, os três critérios para garantir a coerência propostas do Bobbio não são suficientes para assegurar a coerência de um sistema de precedentes. Nesse tocante, Hart, Raz e Ross também não apresentam alternativas em seus modelos. Devem ser, portanto, abandonados seus termos absolutos, em prol de um critério mais amplo de harmonia.

O formalismo, por sua vez, não se adequa a um sistema de precedentes, porque suas debilidades gerais para o Direito se mostram ainda mais evidentes nesse âmbito específico. Menezes Cordeiro bem resume em dois motivos a falência da estrutura sistêmica formal: a) incapacidade de o formalismo lidar com o caráter histórico-cultural do Direito, pois "a sua configuração apresenta-se, pelo menos no seu actual estádio dos conhecimentos humanos, como o produto de uma inabarcável complexidade casual que impossibilita, por completo, explicações

\footnotetext{
${ }^{3}$ Nesse aspecto, escreveu o Ministro Dias Toffoli em seu voto: "Então, senhor Presidente, firme nesses precedentes - para mim, fica claro que aquele caso foi um caso isolado da Primeira Turma, que está, inclusive, sob embargos de divergência, ou seja, não transitou em julgado, ainda sub judice -, mantendo-me coerente com o que votei em relação ao plenário virtual, entendo que não há no caso matéria constitucional, não se abrindo, portanto, à análise”.

${ }^{4} \mathrm{Na}$ apelação Cível no 70030515795, o Relator, Desembargador Ricardo Moreira Lins Pastl escreveu: “Anoto não desconhecer a recente decisão do STF que, ao julgar o RE $\mathrm{n}^{\circ} 428.991 / \mathrm{RS}$ ( $1^{a}$ Turma, publicação no DJE em 31.10.2008), deferiu o reajuste pretendido. No entanto, tenho ser prematura a adoção deste entendimento, posto que esposado em um único julgado isolado, da relatoria do eminente Min. Marco Aurélio (acompanhado pelos Ministros Ricardo Lewandowski e Menezes Direito, ausentes justificadamente os Ministros Cármen Lúcia e Carlos Britto). Impera destacar, todavia, que as decisões anteriores proferidas pela Primeira Turma do Pretório Excelso são em sentido diverso (assim, v. g., AI-AgR 471741/RS, Min. Cezar Peluso, DJ 19-08-2005), coadunando-se com a compreensão desta $4^{\text {a }}$ Câmara Cível. Destaco, outrossim, que recentemente, em maio do corrente ano, a colenda Segunda Turma do Supremo Tribunal Federal, nos autos do AI 459100 AgR/RS (de relatoria do Ministro Joaquim Barbosa, o qual restou acompanhado pelos Ministros Cezar Peluso, Eros Grau e Ellen Gracie, ausente justificadamente o Ministro Celso de Mello, DJE de 19/06/2009), decidiu pelo não cabimento da interposição de Recurso Extraordinário em relação à temática ora estudada, pois a matéria de fundo seria infraconstitucional, o que não impediu que o eminente Ministro Relator consignasse, ainda, que, "no que concerne à suposta omissão do Executivo estadual, observo que incumbe apenas a esse Poder a edição dos atos normativos que viabilizem a execução de suas leis, não cabendo ao Poder Judiciário, que não tem função legislativa típica, editar normas, sob pena de violação do art. $2^{\circ}$ da Constituição Federal”.
} 
integralmente lógicas e racionais" (CANARIS, 2002, p. XIX-XX); e b) incapacidade do formalismo ante a riqueza dos casos reais, porquanto, "na verdade, todas as construções formais assentam num discurso de grande abstração e, como tal, marcado pela extrema redução das suas proposições" (2002, p. XX). Em seguida, o autor, vaticina que, "quando invocados para resolver casos concretos, tais proposições mostram-se insuficientes; elas não comportam os elementos que lhes facultem acompanhar a diversidade de ocorrências, e daí soluções diferenciadas" (CANARIS, 2002, p. XX).

Diz-se que essas insuficiências gerais se mostram mais expressivas no sistema de precedentes porque o juiz, ao julgar, realiza justamente a mediação entre o Direito e a realidade, é nesse ato que ele constrói solução dialética de um caso concreto em função da contraposição dos vários argumentos das partes, que devem ser enfrentados na fundamentação. Tudo isso, enriquece do ponto de vista hermenêutico o ordenamento jurídico, sendo o dado característico e a função precípua do sistema de precedentes. Não se faz pesquisa de jurisprudência para se buscar o que já está expresso no texto da lei ou da constituição, busca-se, em verdade, significados novos, obtidos quando o enunciado é submetido a situações concretas, reais, sendo que tudo é apresentado de maneira justificada e fundamentada. Não se pode jogar tudo isso fora para reduzir precedentes a uma norma geral e abstrata com a rígida estrutura "Se f, então Sc".

Melhor sorte não tem o positivismo, com sua neutralidade axiológica e material. Um precedente pode, sim, perder força se for injusto, incoerente ou de alguma maneira não espelhe o conjunto de princípios que subjaz à série de decisões políticas e valorativas que perpassam o ordenamento.

Por tudo isso, não podem ser os precedentes organizados segundo a mesma estrutura sistemática das normas legislativas. Eles formam um sistema próprio, que não é estruturado em pirâmide, mas em rede, cujas relações não se dão por lógica formal, mas dialética em função da força que apresentam em razão de uma série de fatos por razões de integridade, coerência e justificação. É em torno disso que se deve construir um paradigma teórico adequado para o sistema de precedentes.

\section{UM NOVO COMEÇO: DIREITO COMO INTEGRIDADE E O SISTEMA COERÊNCISTA DE PRECEDENTES}

\subsection{Sistema jurídico e integridade: uma reconstrução a partir das ideias de Dworkin}

Como exposto no item anterior, a neutralidade material positivista, o formalismo jurídico, a unidade hierárquica e a coerência obtida pelos critérios de solução de antinomias (tudo a formar um sistema fundacionalista) são os pontos da teoria clássica do ordenamento jurídico que geram uma incompatibilidade com a sistematização de precedentes. É preciso, pois, que o novo modelo proposto supere esses quatro obstáculos (e de um modo geral o modelo fundacionalista), o que se acredita poder ser feito a partir da compreensão do Direito como integridade de Ronald Dwokin, que evita o positivismo e o formalismo jurídico, autorizando uma unidade obtida por relações dialéticas e a expansão da coerência para a integridade. Muda-se, então, o paradigma fundacionalista de sistema para um coerentista.

Estefânia Maria de Queiroz Barboza (2014, p.247) também entende ser o direito como integridade de Dworkin o meio apropriado para enfrentar os precedentes judiciais no atual estágio de desenvolvimento da Teoria do Direito, que não pode se pautar apenas em critérios formais, demandando consideração de aspectos substanciais de justiça e moral, próprio dos princípios. Daí por que ela afirma que a compreensão desses aspectos, desde o common law, "envolviam interpretações do direito à luz de uma teoria da filosofia moral e política evidenciada por uma tradição cultural e intelectual específica, o que seria exatamente o que Dworkin sustenta". Com isso, denuncia haver precedentes que parecem ser justos e válidos apenas 
isoladamente, mas que se apresentam incompatíveis quando cotejados com o contexto principiológico e mesmo da cadeia jurisprudencial que lhe precede.

Dworkin constrói seu pensamento, então, entendendo que o Direito não pode ser concebido como um sistema fechado, em que o ingresso de elementos nele só seja autorizado por uma regra de reconhecimento - compreendida estritamente como um teste de pedigree -, pois os princípios jurídicos representam o ingresso de valores morais no Direito. Essa inserção da moral no Direito mediante a compreensão dos princípios jurídicos em uma dimensão deontológica importa uma superação da neutralidade positivista em relação ao conteúdo das disposições jurídicas. Por esse motivo, a análise das normas constitucionais, legislativas e, também, dos precedentes não pode se dar de maneira neutra, demanda uma análise de seu conteúdo, a fim de aferir sua coerência, integridade e, nos precedentes, a justificação.

A coerência e a integridade em Dworkin são apresentadas segundo uma visão interpretativista do Direito, em substituição ao que ele chama de teorias semânticas do Direito, como o positivismo, em que se busca um conjunto de critérios gerais para definir de maneira ampla e atemporal o que deve ser qualificado como Direito. Ele defende que o jurídico é compreendido em função de uma atitude interpretativa, tal qual ocorre com a interpretação da arte. Nesse tocante, cita e segue, ainda que não fielmente, o raciocínio de Gadamer para quem há a libertação do conhecimento pela experiência da arte. A compreensão se dá não por apego a métodos rígidos, mas porque a linguagem de um modo geral evoca elementos da cultura e da historicidade para dar sentido aos elementos jurídicos, elidindo, pois, o subjetivismo da intenção de quem expede os textos.

Essa dimensão dada pela cultura e historicidade evita justamente a postura semântica de definição de critérios formais em torno de regras básicas necessárias para se entender de maneira firme e perene o que seja Direito. Recorre à figuração de Wittgenstein "de uma corda constituída de inúmeros fios dos quais nenhum corre ao longo de todo o seu cumprimento nem a abarca em toda sua largura" (DWORKIN, 1999, p. 85). Do mesmo modo, o que se pode entender por Direito não possui um único fío condutor em toda a sua compreensão histórica, mas um entrelaçamento de conceitos e elementos que se fundem em um todo concatenado. Em suas palavras, "o direito como integridade, portanto, começa no presente e só se volta para o passado na medida em que seu enfoque contemporâneo assim o determine" (DWORKIN, 1999, p. 274).

Propõe que os princípios organizam e justificam a prática jurídica atual, razão pela qual "o direito como integridade deplora o mecanismo do antigo ponto de vista de que 'lei é lei', bem como o cinismo do novo 'realismo'. Considera que esses dois pontos de vista são enraizados na mesma falsa dicotomia entre encontrar e inventar a lei" (DWORKIN, 1999, 274). Sua ideia de chain novel (romance em cadeia) nasce de seu recurso à literatura para expor suas posições. Escreve:

Ao decidir o novo caso, cada juiz deve considerar-se como parceiro de um complexo empreendimento em cadeia, do qual essas inúmeras decisões, estruturas, convenções e práticas são a história; é seu trabalho continuar essa história no futuro por meio do que ele faz agora. Ele deve interpretar o que aconteceu antes porque tem a responsabilidade de levar adiante a incumbência que tem em mãos e não partir em uma nova direção. Portanto, deve determinar, segundo seu próprio julgamento, o motivo das decisões anteriores, qual realmente é tomado como um todo, propósito ou o tema da prática até então" (DWORKIN, 2005, p. 237-38).

Coerência e integridade, agora exigidos expressamente pelo art. 926 do Código de Processo Civil, muito se aproximam, ao ponto de Dworkin se perguntar: "Será a integridade apenas coerência (decidir casos semelhantes da mesma maneira), sob um nome mais grandioso?" 
(DWORKIN, 2005, p, 263) O próprio autor informa que isso merece cuidado, por depender do conceito de coerência que se utilize ou mesmo a noção que se tenha de "casos semelhantes". Contudo, assenta que "se uma instituição política só é coerente quando repete suas próprias decisões o mais fiel ou precisamente possível, então a integridade não é coerência; é, ao mesmo tempo, mais e menos". Daí acrescenta:

A integridade exige que as normas públicas da comunidade sejam criadas e vistas, na medida do possível, de modo a expressar um sistema único e coerente de justiça e equidade na correta proporção. Uma instituição que aceite esse ideal às vezes irá, por essa razão, afastar-se da estreita linha das decisões anteriores, em busca de uma fidelidade aos princípios concebidos como mais fundamentais a esse sistema como um todo.

Como se lê, a coerência estrita das leis e também dos precedentes é apenas a reprodução de uma linha de entendimento anterior, tem por referência apenas esse encadeamento prévio, que deve ser reproduzido. Por outro lado, a integridade é diferente, revela um compromisso, uma convergência não apenas com uma linha isoladamente considerada, mas uma harmonia com outros elementos, especialmente principiológicos, do sistema jurídico considerado em sua inteireza, e não apenas do modo revelado pelo encadeamento imediatamente anterior.

Não se pode, porém, afirmar que a integridade importe uma incoerência, porque a integridade pressupõe sintonia com os princípios e demais disposições do sistema jurídico que também servem - ou deveriam servir - de parâmetro para a linha anterior. Seria, assim, uma coerência com o parâmetro mais amplo e, em especial, principiológico.

Lenio Streck (2016, p. 171) conjuga ambos para apontar que "decisão íntegra e coerente quer dizer respeito ao direito fundamental do cidadão frente ao Poder Público de não ser surpreendido pelo entendimento pessoal do julgador, um direito fundamental a uma resposta adequada à Constituição". Por essa razão, arremata que "decidir com integridade e coerência é um dever e não uma opção ou escolha".

Seguindo Dworkin, é possível afirmar que a integridade, em relação aos precedentes, é uma imposição dinâmica, pois incentiva o juiz ou tribunal a ser mais abrangente, a ir além da linha jurisprudencial estrita, do precedente isoladamente apreendido ou da literalidade da súmula. Impõe que o juiz ou tribunal vá a busca de uma convergência com o princípio fundamental que dá o tom de harmonia à jurisprudência que liga os julgados autorizadores da súmula e que toque o ganho hermenêutico do precedente; tudo em função do jogo interpretativo. É justamente em torno desse ganho hermenêutico, que permite o desenvolvimento do Direito, que David Panick (1980, p.36-43) entende compatível a doutrina do stare decisis com a teoria de Dworkin, em especial em sua versão anterior à publicação de "O Império do Direito". Escreve o autor: "The only strong defense open to Dworkin is to argue that precedent is required by the right thesis, and is based on fairness in giving the litigants their entitlements, because the earlier decision developed the law in some way".

Especificamente sobre a relação entre stare decisis e integridade, Scott Hershovitz (2012) destaca que a integridade exige dos tribunais o reconhecimento de que o decidido no passado afeta aquilo que devem fazer no futuro, sendo, pois, uma atividade engajada com sua história, não apenas cegamente reproduzindo o que foi feito anteriormente, mas também distinguindo e superando.

O mesmo autor busca, então, verificar a validade do argumento de que o stare decisis poderia se justificar independentemente do mérito do precedente. Para tanto, ele lança mão da ideia de autoridade da corte emissora e a proposta de Raz de justificação comum para se seguir tal autoridade, a qual parte da premissa de que a decisão de uma autoridade deve ser seguida independentemente de seu mérito quando ela tenha melhores condições de resolver adequadamente a questão. Isso, então, justificaria uma corte inferior respeitar o precedente de 
uma corte superior, já que os tribunais recursais, formado por magistrados mais experientes e mediante um contraditório ampliado por argumentos contra a própria decisão de primeiro grau, teriam uma posição melhor para decidir. Contudo, essa explicação não alcançaria a força horizontal dos próprios precedentes do específico tribunal. Com efeito, levar a sério o stare decisis impõe observância também aos precedentes da própria corte.

Dada essa falha do argumento de autoridade, Hershovitz expõe que os tribunais também são atores morais e, enquanto tais, devem seguir seus próprios precedentes e dos tribunais superiores em função de um dever moral de compromisso com entendimento já exposto ao longo do tempo. Não é moralmente adequado agir de maneira caprichosa em questões de importância. É possível divergir sobre o que seria o seria certo decidir, mas, uma vez decidido, não se pode arbitrariamente variar no futuro. O próprio Dworkin, em comentário a esse texto, afirma que Hershovitz bem aplicou suas ideias ao stare decisis.

Dessa forma, exclui-se do Direito o positivismo, porque integra Direito e moral, exigindo uma compreensão de sistematização de modo que o conteúdo de suas partes integrantes importe e interfira nas mútuas relações. Em igual medida, afasta o formalismo, porque renega o "filtro" em porta de entrada no sistema, de modo a permitir ingresso apenas de aspectos formais, pelo que os componentes do ordenamento jurídico não podem ser reduzidos ao que se estrutura em torno de arquétipos formais.

Especificamente em relação aos precedentes, Dworkin alerta com toda propriedade que os tomar como leis, e em especial em uma formal estrutura "Se f, então Sc", e aplicar-lhes os métodos interpretativos destas é um erro. Os motivos que fazem dos precedentes parâmetros de conduta e julgamento não são os mesmos de seguir as leis, que se fundam na teoria democrática geral. Embora em um precedente se possa encontrar uma enunciação canônica semelhante à de uma lei, no sentido de trazer uma prescrição geral e abstrata, ele não pode ser resumido a isso.

Com substrato nessa constatação, ele trabalha com a distinção entre a força de promulgação e a força gravitacional, esta específica dos precedentes. A força de promulgação consiste na produção, pelo precedente, de uma norma em moldes parecidos com uma legislativa. Essa é a dimensão que vem sendo destacada pela doutrina nacional. "Não obstante, descobrirá que, quando um precedente tem força de promulgação, não se considera que sua influência sobre casos posteriores se limite a essa força" (DWORKIN , 2002, p. 174). O juiz "insistiria em que a decisão anterior exercer uma força gravitacional sobre as decisões posteriores" (DWORKIN, 2002, p. 174). Por sua vez, a "força gravitacional do precedente não pode ser apreendida por nenhuma teoria que considere que a plena força do precedente está em sua força de promulgação, enquanto uma peça de legislação" (DWORKIN, 2002, p. 176).

Portanto, Dworkin aceita a ideia de que os precedentes forneçam padrões que exerçam influência nas decisões posteriores, uma vez que "contribuem na formulação de regras novas e controvertidas de uma maneira distinta do que no caso da interpretação" (DWORKIN, 2002, p. 175). Refuta, porém, a noção de que isso se dê nos moldes de uma norma legislativa que se impõe inarredavelmente por simplesmente ter sido posta por um tribunal, ficando a depender da ocorrência de outros fatores que aumentam ou diminuem a influência sobre o caso posterior.

A contraposição das ideias de Dworkin a Kelsen é clara, pois, como visto, este põe o precedente na condição de uma norma geral e abstrata obtida por meio da ampliação da norma de julgamento utilizado. Kelsen faz isso porque seu sistema jurídico é composto apenas e tão somente de normas com a estrutura "Se f, então Sc". Contudo, embora se possa encontrar no precedente, ou erigir dele, uma norma nesses moldes, em razão de sua força de promulgação, não será apenas a ela que o precedente será reduzido. Há um conjunto maior de elementos que importam em sua força gravitacional variável, a qual se prefere denominar de força hermenêutica.

Como o precedente não se reduz a sua força de promulgação, de modo a impedir que se o tome apenas como norma com estrutura formal reduzida, fica demonstrado que a teoria positivista de sistema jurídico com seu respectivo formalismo, que consideram o sistema apenas 
integrado por normas com essa precisa estrutura formal, é com ele incompatível, demandando novo modelo próprio. Eis, pois, porque em nenhum modelo positivista os precedentes são bem posicionados. Em verdade eles formam um subsistema próprio e diferenciado do subsistema de normas. Esses dois subsistemas compõem o ordenamento jurídico.

\subsection{O modelo complexo e heterogêneo de sistema jurídico formado por dois subsistemas}

Para construir esse novo modelo a partir do referencial do Direito como integridade, as lúcias lições de Rodrigo Azevedo Greco são fundamentais, pois ele apresenta os elementos básicos e necessários para a descrição de um sistema jurídico, os quais retira da Teoria Geral do Sistemas.

Destaca o autor que a Teoria Geral dos Sistemas foi idealizada inicialmente por Ludwig von Bertalanffy, que preconiza a superação do método cartesiano de compreensão obtida pela "repartição do objeto de análise em um número finito de parcelas, até o ponto em que não fosse mais possível reparti-las, ou, então, até onde uma nova repartição não aumentasse o grau de conhecimento sobre uma determinada parcela, para, em seguida, se reconstruir o objeto de análise, ordenando-se o pensamento com base nas parcelas mais simples e fáceis de conhecer e elevando-o até o conhecimento total do objeto, sem nada omitir" (GRECO, 2015, p. 15). Esse tipo de conhecimento cartesiano só se viabiliza e é adequado caso a interação entre as partes do objeto estudado não exista ou, em existindo, sejam fracas ao ponto de poderem ser desprezadas, o que, via de regra, não é tão comum ocorrer. Daí o conhecimento do sistema não pode cindir o estudo do objeto em partes, demandando o conhecimento do todo sistêmico indissociado. Para ele, "o sistema é um objeto que (i) está inserido em um determinado meio, (ii) está voltado para uma finalidade, e, para tanto, (iii) faz ou desempenha uma atividade, (iv) por intermédio de uma estrutura, (v) que se transforma com o tempo" (GRECO, 2015, p. 45). Por essa razão, todo sistema possui cinco pontos fundamentais que o define: a) meio circundante; b) finalidade; c) estrutura; d) atividade; e e) evolução.

O meio circundante é aquilo que é externo ao sistema e no qual ele está inserido. Há uma troca inevitável entre o sistema e seu meio circundante, que pode ser, inclusive, um outro sistema. O sistema específico de precedentes (ou subsistema jurídico de precedentes) tem como meio circundante mais próximo o sistema específico de normas legislativas, constitucionais e regulamentares (ou subsistema jurídico normativo). A troca entre esses dois sistemas específicos (subsistemas) que formam o sistema jurídico (ordenamento jurídico) é proveitosa para ambos, pois é justamente essa troca que evita que as interações apenas internas das partes do subsistema tendam para uma desestruturação. As trocas externas, portanto, são essenciais e inexoráveis.

No caso dos subsistemas em análise, é possível dizer que, de um modo geral, o sistema de precedentes enriquece o sistema normativo com ganhos hermenêuticos que somente podem ser obtidos em função do caso concreto, mediante análise dialética de argumentos e contraargumentos (esta é sua principal função e finalidade). Basta relembrar que o regime jurídico das comissões parlamentares de inquérito -CPI, o conceito de vida e de casa para fins de definição do alcance da Constituição Federal foram enriquecidos por precedentes do Supremo Tribunal Federal, que firmaram conceitos e admitiram entendimentos indispensáveis para apreender o texto constitucional. Dessa maneira, os precedentes moldam o trato desses sentidos normativos, evitando uma interminável disputa interpretativa em torno deles.

Por sua vez, o subsistema normativo viabiliza (mediante a disposição constitucional que reconhece a jurisdição) e organiza o sistema de precedentes, sobretudo após o Código de Processo Civil de 2015, que regra as várias interações internas entre precedentes, permitindo, assim, maior harmonia entre eles, combatendo a jurisprudência lotérica existente até então, cujo um dos principais motivos é justamente a falta de disciplinamento normativo da relação entre precedentes. Em outras palavras: por não haver, até então, trocas mais intensas no sentido do 
subsistema normativo para o subsistema de precedentes, este era regido eminentemente por relações internas, que tenderam a uma desordem demonstrada pela formação da jurisprudência lotérica. Com a edição do novo Código, essas trocas intersistêmicas serão mais intensas, porque o ordenamento normativo traz uma série de disposições que irão atuar sobre o subsistema de precedente, e essa interação com esse meio circundante diminuirá a entropia interna. A principal disposição do novo diploma nesse sentido é a do art. 926, que estatui a finalidade de os tribunais uniformizarem sua jurisprudência, mantendo-a estável, íntegra e coerente.

Identifica-se mesmo a relação entre subsistemas de precedentes, ou seja, entre o conjunto de precedentes de cada tribunal com o conjunto de precedentes de outro tribunal, pois é necessário compreender que há mútua interação entre as várias cortes, independentemente de sua hierarquia. Por via de consequência, aquele tribunal que se mantiver isolado, sem observar qualquer outro julgado, tende à desordem e à arbitrariedade. Por essa razão, não se pode, por exemplo, deixar os subsistemas de precedentes das cortes de cúpula, em especial do Supremo Tribunal Federal, alheios à interação com julgados de outras cortes inferiores, porque haverá uma tendência à instabilidade, à desordem e à arbitrariedade. Mas essa interação não pode ser apenas de cima para baixo, ou seja, dos precedentes do Supremo em relação aos precedentes das outras cortes, pois isso significaria que o conjunto de precedentes do próprio Supremo ficaria isolado, sem receber trocas oriundas dos outros sistemas, tendendo, então, à desordem. Por isso, necessário se admitir uma relação não apenas unidirecionais de cima para baixo, mas também simétricas (conhecidas também como circulares), porque as cortes mais elevadas não podem deixar de considerar o que outros tribunais fazem, sob pena de ocasionarem o caos, a arbitrariedade em seu próprio conjunto de precedentes.

Essa tendência à desordem na hipótese de um sistema ou subsistema se manter isolado se deve a sua entropia interna, entendida como a tendência natural à desordem. Essa tendência à desordem de sistemas que se mostrarem fechados é explicada por Rodrigo Azevedo Greco (2015, p. 58): "Isso ocorre porque a quantidade de estados desordenados do sistema supera, em muito, a quantidade de estados ordenados e, portanto, a probabilidade de o sistema, ao longo do tempo, caminhar para um estado de desordem é muito maior do que a probabilidade de o sistema caminhar para um estado ordenado".

Portanto, como há necessidade de trocas não só do subsistema de precedentes com o subsistema normativo, mas também entres os vários subsistemas de precedentes das mais diversas direções, as relações entre as partes são simétricas (circulares), quebrando a estrutura piramidal e hierarquizada.

Com efeito, no tocante à estrutura do sistema, Rodrigo Azevedo Greco (2015, p. 48) explica que as relações entre seus elementos podem ser de duas formas, abertas (também conhecidas como lineares ou assimétricas) ou fechadas (circulares ou simétricas). Nas primeiras, a interação obedece um único sentido, permitindo uma hierarquização ou escalonamento. Sistemas em que as relações entre as partes são apenas lineares, adquirem estrutura piramidal. Nas segundas, a interação entre as partes tem mútuo sentido, uma influenciando e condicionando a outra, formando, pois, uma estrutura em rede. Quando um sistema tem as duas espécies de relação forma uma estrutura híbrida de hierarquia entrelaçada.

No caso do subsistema de precedentes, não se pode falar que haja apenas relação simétrica entre eles, mesmo porque um precedente de um tribunal inferior não é uma derivação por delegação de um precedente superior. Todo e qualquer precedentes tem por fundamento de validade a Constituição. A hierarquia da corte que o emite, portanto, não é causa de hierarquia entre os precedentes, mas, certamente, interfere em sua força hermenêutica para determinar e condicionar a relação não só formal, mas também material com outros precedentes.

A estruturação das partes em conjunto, sem contradições, não pode se dar, por isso, nos padrões hierárquicos formais, justamente porque se tem partícula maleável (sentido). As interações são intensas e complexas: não há um fundamento de validade calcado em um só ponto 
de nível mais elevado nem uma validação vertical de um estrato inferior. Há uma rede de relações.

Abandona-se, pois, a figura piramidal e hierarquizada em prol de uma estrutura em rede. Deixam-se as relações assimétricas dedutivas unidirecionais ("de cima para baixo") para se ter uma lógica dialética policêntrica. Cada integrante da rede jurídica encontra mútuos fundamentos de validade, e não somente um pontual superior. Também as partes superiores não servem apenas para fundamentar as inferiores (numa relação unidirecional assimétrica), elas se fortalecem mutuamente.

É nesse sentido o sistema descrito por Bermejo e que bem se aplica ao sistema de precedentes: "Sabemos que el sistema ha de ser reconstruido en el curso de un proceso interpretativo a propósito de un caso" (BERMEJO, 2006, p. 126). Essa expressão ressalta os efeitos da integração de compreender, interpretar e aplicar: tudo gira em torno da consideração de um caso que se quer regular/aplicar com o enunciado, e as características desse caso podem variar por interferências teóricas ou reais. Como destaca o mesmo autor, ante uma demanda de justificação, todos os elementos atuam de maneira integrada e solidária, de forma a todos os elos poderem atuar inclusive em áreas normalmente estranhas ao seu campo normal de aplicação. Toda aplicação, portanto, acontece em uma integridade que demanda uma coerência ampla.

Essa atividade do sistema (terceiro dos cinco elementos fundamentais) também segue padrões de medidas de proteção e fomento. Rodrigo Azevedo Grego (2015, p. 45-47) indica que as medidas protetivas são de duas espécies, diretas e indiretas. As diretas impedem, inclusive por coação, a prática da conduta indesejada, enquanto as indiretas dificultam ou desestimulam a prática, tornando-a desvantajosa. As medidas promocionais também podem ser diretas ou indiretas. As primeiras são aquelas que compelem o indivíduo a ser comportar da maneira intencionada. Por sua vez, as segundas (medidas promocionais indiretas) estimulam, incentivam a conduta, facilitando sua prática. O precedente é moldado por outras decisões, independentemente do nível hierárquico da corte que as produz, já que há uma interação mútua que não gira em torno apenas da hierarquia.

Um precedente é reforçado na medida em que ganha apoio e interação com outros julgados posteriores no mesmo sentido, quando é refletido na legislação e incorporado na prática administrativa. Para tanto o novo Código de Processo Civil, por exemplo, dota alguns precedentes de medidas protetivas (como instrumento da reclamação) ou promocionais (como a possibilidade de julgamento monocrático pelo relator ou indeferimento liminar de ação no primeiro grau). Além disso, todo precedente passou a desfrutar do dever de ser adequadamente analisado na fundamentação da decisão, por força do art. $489, \S 1^{\circ}$ do novo diploma. Esse tipo de medida estipula o reforço a esses precedentes tornando-os mais forte. Esse reforço mediante a conexão estimulada com outros integrantes do sistema jurídico denota relações que não são formais, mas materiais. Quanto mais apoios (conexões) um precedente angaria na rede sistêmica, mais força ele terá. Por outro lado, na medida em que os jugados posteriores desafiam o precedente, em que ele não é reverberado nas práticas legislativas ou administrativas e em que ele é criticado pela doutrina, ele perde elos sistêmicos, enfraquecendo-se até se tornar-se irrelevante. Quanto menos conexões sistêmicas possui um precedente, mais frágil ele vai se tornando até ser considerado irrelevante e expurgado do sistema.

Essa constante e mútua interação entre as várias partes do subsistema de precedentes entre si e com os demais elementos do ordenamento jurídico, em especial os princípios, molda 
seu desenvolvimento. Quando as interações de reforços se somam, ou seja, quando há várias e intensos apoios em princípios, regras e outros precedentes, criam-se precedentes centrais, verdadeiros "entroncamentos" na rede que compõem, atraindo para si a compreensão de vários outros julgados e mesmo das normas jurídicas. Por exemplo, o precedente do Supremo Tribunal Federal sobre a constitucionalidade da união homoafetiva é indiscutivelmente um dos entroncamentos materiais da rede de precedentes, pois molda vários outros julgados em vários outros ramos do direito, como previdenciário, tributário, família etc, sem falar que emprestou sentido para ponto fulcral da Constituição Federal. É dessa maneira que se formam os superprecedentes anteriormente aludidos.

Dessa forma, não há um sistema axiomático, fechado e hierarquizado, tipicamente fundacionalista, cuja unidade e coerência são formais. Emerge um sistema coerentista (termo retirado da epistemologia jurídica). Bermejo (2006, p. 126) destaca as linhas de tipo de precedente erigido do Direito como integridade:

Los presupuestos interpretativos y problemáticos de Dworkin sugieren la concordancia de su sistema con lo que en teoría del conocimiento se ha denominado modelo coherentista. En primer lugar, el punto de vista de la aplicación convoca diversos principios igualmente válidos, exige un examen del peso e importancia de los mismos, e implica una ponderación juiciosa, el recurso a nuevos juicios de desempate...operaciones que pronto juzgaremos como familiares e idiosincrásicas del modelo coherentista de sistema. E, en segundo lugar, el giro interpretativo de Dworkin, adornado de reconocimientos explícitos a Gadamer, nos coloca en la pista de otro dibujo de coherencia circular como es el del círculo hermenéutico, hito anti-fundacionalista de la filosofía contemporánea.

As características desse novo modelo de sistema coerentista propõem uma nova forma de harmonia interna a ser conservada entre as partes que o compõem. Em vez de uma compatibilidade lógico-formal, trabalha-se com uma noção mais ambiciosa. Tem-se, assim, uma tese holística de justificação, ou seja, um sentido jurídico só será justificado se capaz de se sustentar os demais sentidos que integram o todo e, ao mesmo tempo, também contribua para a sustentação de todas as demais no sistema.

Outra característica do sistema coerentista é a negação de axiomas: postulados autoevidentes que prescindem de fundamentação, mas que respondem pelo ingresso das partes no conjunto mediante a imposição de critérios formais (algoritmos). No novo modelo, qualquer parte demanda justificação, integridade e coerência com as demais. Não se admitem, pois, preceitos fundamentais de que são inferidos os demais, mas que não são inferidos de outro superior. Não se tem uma base que sustenta toda estrutura, mas que se sustenta a si mesma no ar.

Conquanto comporte relações de lógica formal, com uma linha dedutiva ou indutiva de justificação, esse novo modelo se caracteriza por juízos de ponderação e força, sem prefixação de relevância ou sentido, comportando, pois, juízos de graduação e medição da relevância de uma parte que se queira aplicar a um determinado caso; e também comporta linha multidirecional de justificação. Essa visão dialogada e multidirecional impede que a corte emissora determine unilateralmente o que seja o precedente ou mesmo sua ratio, bem explicando uma realidade já consolidada nos países de tradição do stare decisis. Cross e Harris (2004, p. 41) indagam na tradição inglesa: "If a judge has this amount of freedom to determine which of his observations is 
ratio decidendi and which obiter dictum, is there not a grave danger that he will exercise an undue influence on the future development of the law?"

A ausência de algoritmos impede se falar em uma lógica binária de pertence/não pertence ao sistema, a qual ocasionaria uma aplicação no tudo ou nada; em pertencendo, se aplica a parte em um grau máximo; em não pertencendo, não serve para qualquer justificação ou aplicação. O ingresso no sistema não se dá nesses termos absolutos, comportando gradação. Isso muda a ideia de vigência, a qual, na sua compreensão positivista e formal, já se viu não se aplicar aos precedentes. Exemplifique-se o que se está a dizer: o fato de haver uma precedente posterior não implica que o anterior com ele contrário vá ser "revogado" (overruled) de uma maneira total e plena, de modo a deixá-lo imprestável para uso posterior; não há uma exclusão automática e radial do sistema coerentista. Certamente, o precedente anterior perderá força hermenêutica, mas não há uma extração abrupta. Caso se reitere, em subsequentes e reiterados julgados posteriores, a mudança de entendimento, é possível se chegar à exclusão total, mas que será gradual e paulatina.

Essa forma de entender impede guinadas radicais de orientação jurisprudencial que pegam de surpresa a todos. Basta lembrar, também, os já apresentados super-precedentes (respostas jurisdicionais arraigadas no sistema pelo tempo e pela repetida utilização); a lógica binária algorítmica não suporta sua correta compreensão, pois um simples desafio por julgados posteriores não causa a sua exclusão do conjunto.

Ademais, a ideia de integridade de Dworkin importa, para a compreensão holística do sistema jurídico, valores como equidade, procedimento devido e justiça, os quais põem abaixo quaisquer critérios de justificação formal e fechado.

O método de argumentação é dialético porque se deve ponderar e considerar os argumentos trazidos pelas partes, o raciocínio completo exposto em todo o precedente e não somente parte isolada. Mesmo o voto vencido, e os votos com fundamentação distinta mas conclusão coerente com a vencedora são importantes para determinar a contribuição hermenêutica que o precedente ocasiona. Também será necessária argumentada ampliação da resposta para situações não expressamente decididas. Os universais e inferências simplórias simplesmente não são suficientes para fundamentar uma decisão na perspectiva constitucional devida.

Como se percebe por todo o exposto, tem-se a proposta de um paradigma teórico novo para a sistematização dos precedentes.

\section{CONCLUSÃO}

A falta de uma reflexão própria sobre a sistematização de precedentes vem causando a aplicação de um modelo clássico de ordenamento jurídico erigido, sob os auspícios do positivismo normativista, para as normas legislativas. Isso tem causado uma equivocada compreensão interação dos vários julgados, submetendo-os a uma relação de hierarquia e formal completamente inadequada à função hermenêutica dos pronunciamentos jurisdicionais para o Direito.

Ao se lançarem luzes especificamente sobre o tema com o referencial teórico do Direito como integridade, emerge uma concepção coerentista de sistema de precedentes, que substitui a rígida pirâmide hierarquizada, com escalões fixos de normas, por uma maleável estrutura em rede, cujas relações se pautam não em uma lógica formal unidirecional (com inferências do superior para o inferior), mas por lógica dialética substancial multidirecional. Percebe-se, então, que o ordenamento jurídico é formado por dois subsistemas, um normativo e outro de precedentes, que exercem entre si uma relação intersistêmica importante para evitar a desorganização e incoerência interna de cada um. 
O novo paradigma teórico para compreensão do ordenamento jurídico é, portanto, de um sistema complexo, heterogêneo e coerentista.

Ele é complexo porque se subdivide em dois subsistemas, um de normas (com estrutura tendente a uma árvore) e outro de precedentes (organizados em rede). É heterogêneo porque não é mais apenas um sistema normativo, já que os precedentes, conquanto possam expressar uma norma ou deles se retirar uma norma, sua compreensão, aplicação e integração no respectivo subsistema não se dá apenas por esse seu aspecto normativo, mas ingressa e faz parte do ordenamento jurídico o todo integrante da decisão base do precedente, com sua fundamentação, eventuais divergências e diálogo hermenêutico.

As disposições do novo Código de Processo Civil que versam sobre precedentes disciplinam a relação interna desse subsistema, atuando como meio circundante que combate a entropia (tendência a desordem) do conjunto de precedentes.

Por fim, o ordenamento jurídico que surge da proposta aqui apresentada deve ser entendido como um sistema coerentista, ou seja, um sistema aberto, nele ingressando princípios por razões de ordem material de justiça e moral, e não porque tenha passado por algum algoritmo formal. A abertura do sistema também afasta a lógica binária de pertence/não pertence ao sistema, podendo se falar de disposições que não são revogados abruptamente, mas paulatinamente mitigadas até serem expurgada do sistema, o mesmo podendo se verificar com um ingresso gradual. Há uma lógica dialética. Ademais, não se tem uma relação hierárquica rígida, sobretudo porque, no subsistema de precedentes, a força hermenêutica que determina sua aplicação ou não no caso posterior varia por razões de ordem formal e material de integridade, coerência e justificação. Não há também no modelo de ordenamento proposto, nenhum elemento dele integrante, seja norma ou precedente, que tenha caráter axiomático, todos dependendo da harmonia principiológica aferida desde o altiplano constitucional para se manter válido e eficaz.

\section{REFERÊNCIAS BIBLIOGRÁFICAS}

BARBOZA, Estefânia Maria de Queiroz. Precedentes judiciais e segurança jurídica: fundamentos e possibilidades para a jurisdição constitucional brasileira. São Paulo: Saraiva. 2014.

CANARIS, Claus-Wilhelm. Pensamento sistemático e conceito de sistema na ciência do direito. 3. ed. Lisboa: Fundação Calouste Gulbenkian, 2002.

CHRISMANN, Pedro Henrique Veiga. Julieta não está pronta para ser Montechho - A união das famílias jurídicas e a necessidade de uma nova metodologia do direito preocupado com precedentes. Revista de Direito Brasileira. São Paulo. V.14.n. 6. p. 3017. maio/ago 2016.

CROSS, Rupert; HARRIS, J.W. Precedent in English Law. New York: Oxford University Press Inc., 2004.

BERMEJO, J.M. Pérez. Coherencia y sistema jurídico. Madrid: Marcial Pons, Ediciones Jurídicas y Sociales, 2006.

BOBBIO, Norberto. Teoria do Ordenamento Jurídico. 10. ed. Tradução Maria Celeste Cordeiro Leite dos Santos. Brasília: Editora da Universidade de Brasília, 1999. 
Ícone, 2006.

O positivismo jurídico: lições de filosofia do direito. Trad. Márcio Pugliesi. São Paulo:

DWORKIN, Ronald. Levando os direitos a sério. Traduzido por Nelson Boeira. São Paulo: Martins Fontes, 2002.

GERHADT, Michael. The power of precendent. New York: Oxford University Press, 2008.

GRECO, Rodrigo Azevedo. Direito e entropia. Fortaleza, 2015.

HART, H.L.A. O Conceito de Direito. São Paulo: Martins Fontes, 2009.

HERSHOVITZ, Scott (org.). Exploring Law's Empire. Oxford. Oxford Universty Press. 2012.

KELSEN Hans. Teoria Pura do Direito. Tradução de João Baptista Machado. São Paulo: Martins Fontes, 1999.

. Teoria Geral do direito e do Estado. Traduzido por Luiz Carlos Borges. São Paulo: Martins Fontes, 2005.

LEAL, Fernando. O formalista expiatório. Leituras impuras de Kelsen no Brasil. Revista Direito GV 19 (2014), p. 245-268.

LOPES FILHO, Juraci Mourão. Os precedentes judiciais no constitucionalismo brasileiro contemporâneo. 2. Ed. Salvador: Juspodivm, 2016.

MACCORMICK, D. Neil; SUMMERS, Robert S.; GOODHAT, Arthur L. Interpreting precedents. Great Britain: Aushgate Publishing Limited, 1997.

PANNICK, David. A note on Dworkin and Precedent. The Modern Law Review 43 (1980), p. 3644.

PEIXOTO, Ravi. Superação do precedente e segurança jurídica. Salvador: Juspodivm, 2015.

RAZ, Joseph. O conceito de sistema jurídico: uma introdução à teoria dos sistemas jurídicos. Trad. Maria Cecília Almeida. São Paulo: Martins Fontes, 2012.

ROSS, Alf. Direito e Justiça. Trad. Edson Bini. Bauru: Edipro, 2000.

STRECK, Lenio Luiz; ALVIM, Eduardo Arruda; LEITE, George Salomão (coordenadores). Hermenêutica e jurisprudência no novo Código de Processo Civil: coerência e integridade. São Paulo: Saraiva. 2016 